\title{
Dyselectrolytemia-management and implications in hemodialysis (Review)
}

\begin{abstract}
DELIA TIMOFTE $^{1 *}$, MARIA-DANIELA TANASESCU ${ }^{2,3}$, ANDRA-ELENA BALCANGIU-STROESCU $^{1,4^{*}}$, DANIELA GABRIELA BALAN ${ }^{4}$, ADRIAN TULIN ${ }^{5,6}$, OVIDIU STIRU $^{7,8}$, ILEANA ADELA VACAROIU ${ }^{9,10}$, ANDRADA MIHAI ${ }^{11,12^{*}}$, POPA CRISTIAN CONSTANTIN ${ }^{13,14}$, CRISTINA-ILEANA COSCONEL ${ }^{15}$, MIHALY ENYEDI ${ }^{5,16}$, DANIELA MIRICESCU ${ }^{17}$ and DORIN IONESCU ${ }^{2,3^{*}}$

${ }^{1}$ Department of Dialysis, Emergency University Hospital, 050098 Bucharest;

${ }^{2}$ Department of Medical Semiology, Discipline of Internal Medicine I and Nephrology, Faculty of Medicine,

'Carol Davila' University of Medicine and Pharmacy, 020021 Bucharest; ${ }^{3}$ Department of Nephrology,

Emergency University Hospital, 050098 Bucharest; ${ }^{4}$ Discipline of Physiology, Faculty of Dental Medicine,

'Carol Davila' University of Medicine and Pharmacy; ${ }^{5}$ Department of Anatomy, Faculty of Medicine,

'Carol Davila' University of Medicine and Pharmacy, 020021 Bucharest; ${ }^{6}$ Department of General Surgery,

'Prof. Dr. Agrippa Ionescu' Clinical Emergency Hospital, 011356 Bucharest; ${ }^{7}$ Department of Cardiovascular Surgery,

Faculty of Medicine, 'Carol Davila' University of Medicine and Pharmacy, 020021 Bucharest;

${ }^{8}$ Department of Cardiovascular Surgery, 'Prof. Dr. C.C. Iliescu' Emergency Institute for Cardiovascular Diseases, 022322 Bucharest; ${ }^{2}$ Department of Nephrology and Dialysis, St. Ioan Emergency Clinical Hospital, 042122 Bucharest;

${ }^{10}$ Department of Nephrology, Faculty of Medicine, 'Carol Davila' University of Medicine and Pharmacy;

${ }^{11}$ Discipline of Diabetes, 'Prof. N. Paulescu' National Institute of Diabetes, Nutrition and Metabolic Diseases, Faculty of Medicine, 'Carol Davila' University of Medicine and Pharmacy, 020021 Bucharest; ${ }^{12}$ Second Department of Diabetes, 'Prof. N. Paulescu' National Institute of Diabetes, Nutrition and Metabolic Diseases, 020474 Bucharest; ${ }^{13}$ Department of Surgery, Faculty of Medicine, 'Carol Davila' University of Medicine and Pharmacy, 020021 Bucharest;

${ }^{14}$ Department of Surgery, Emergency University Hospital, 050098 Bucharest; ${ }^{15}$ Discipline of Foreign Languages,

Faculty of Dental Medicine, 'Carol Davila' University of Medicine and Pharmacy, 020021 Bucharest;

${ }^{16}$ Department of Radiology, 'Victor Babes' Private Medical Clinic, 030303 Bucharest; ${ }^{17}$ Discipline of Biochemistry,

Faculty of Dental Medicine, 'Carol Davila' University of Medicine and Pharmacy, 020021 Bucharest, Romania
\end{abstract}

Received July 10, 2020; Accepted August 11, 2020

DOI: $10.3892 /$ etm.2020.9534

\begin{abstract}
Hemodialysis is a method for the renal replacement therapy followed by series of acute and chronic complications. Dyselectrolytemia appears in patients undergoing dialysis through mechanisms related to the chronic kidney disease and/or to the dialysis therapy and for this group of patients it is associated with an increase of morbidity and mortality. The dialysate has a standard composition, which can be
\end{abstract}

Correspondence to: Dr Andra-Elena Balcangiu-Stroescu, Department of Dialysis, Emergency University Hospital, 169 Spaiul Independenţei, 050098 Bucharest, Romania

E-mail: stroescu_andra@yahoo.ro

*Contributed equally

Key words: hemodialysis, dyselectrolitemias, sodium, potassium, calcium, mortality modified according to the patient's characteristics. During hemodialysis patients are exposed to 18,000-36.000 litres of water/year, and the water purity along with the biochemical composition of the dialysate are essential. The individualization of the dialysis prescription is recommended for each patient and it has an important role in preventing the occurrence of dyselectrolyemia. The individualization of the treatment prescription according to the blood constants of each patient is the prerogative of the nephrologist and the association of the electrolyte imbalances with the patients cardiovascular mortality explains the importance of paying special attention to them.

\section{Contents}

1. Introduction

2. Sodium $\left(\mathrm{Na}^{+}\right)$

3. Potassium $\left(\mathrm{K}^{+}\right)$

4. Calcium $\left(\mathrm{Ca}^{2+}\right)$

5. Conclusions 


\section{Introduction}

The patient with chronic kidney disease undergoing renal replacement therapy (RRT) by hemodialysis presents series of complications due to the development of the disease and also to the therapeutic method. The kidney plays an important role in the maintaining of the fluid, electrolyte and acid-base balance, and the progressive loss of renal functions causes dyselectrolitemia, which is correlated to the mortality of the dialysis patient. The standard composition of the dialysate has been the subject of many controversies and many changes over time, in an attempt to re-establish the electrolytic balance through hemodialysis. The 'ideal' dialysate is a synthetic liquid containg all the elements of the normal plasma which allows the elimination of excess substances generated in the blood of the uremic patients and the supply of certain substances in their blood, through processes typical for hemodialysis (1). Dialysate solution commonly contains six electrolytes: Sodium $\left(\mathrm{Na}^{+}\right)$, potassium $\left(\mathrm{K}^{+}\right)$, calcium $\left(\mathrm{Ca}^{2+}\right)$, magnesium $\left(\mathrm{Mg}^{2+}\right)$, chloride $\left(\mathrm{Cl}^{-}\right)$, and bicarbonate $\left(\mathrm{HCO}_{3}^{-}\right)$. The nonelectrolyte component glucose or dextrose is invariably present in the dialysate. The dialysate is considered a 'drug' administered to all dialysis patients; therefore, its composition is essential. The electrolytic changes caused by the contact of the blood with the dialysate, through the semipermeable membrane of the dialyzer, can trigger immediate or long-term effects, with an impact on mortality (1).

\section{Sodium $\left(\mathrm{Na}^{+}\right)$}

Biological role of sodium. Sodium is a cation present in ionized state in all body fluids, especially in the extracellular space (98\%). The maintenance of the electrolyte balance on each side of the cellular membrane requires active transmembrane exchanges through $\mathrm{Na}^{+} / \mathrm{K}^{+}$-ATP-ase (2). Water motion between compartments with the preservation of plasmatic osmolarity and indirectly of the intracellular tonicity and cellular volume represents $\mathrm{Na}^{+}$main role in the body (1). The fluid volume in the extracellular compartment depends directly on the overall amount of sodium in the body, and the concentration of plasma sodium equals that of the interstitial fluid. $\mathrm{Na}^{+}$ movement on each side of the cellular membrane, to achieve electrical balance, involves $\mathrm{Cl}^{-}$and $\mathrm{HCO}_{3}^{-}$, thus promoting the maintenance of the acid-base balance. $\mathrm{Na}^{+}$is also involved in the neuromuscular excitability and in the polarization and depolarization of the cellular membrane (action potential), opposing the potassium effects. The normal range of serum $\mathrm{Na}^{+}$in adults are: $135-145 \mathrm{mmol} / \mathrm{l}(135-145 \mathrm{mEq} / \mathrm{l})(3)$ and its variations could be used as predictors of prognosis in other pathologies $(4,5)$.

An intake of 3-5 grams of salt in $24 \mathrm{~h}$ is enough for a healthy adult, a quantity which replaces the urinary and the cutaneous losses and prevents the negative sodium balance. Diabetics represent a special group when considering adults with different pathologies. Their sodium intake should be limited to 1.5-2.3 g/day, since a more drastic decrease in these patients may trigger insulin resistance, with subsequent negative impact on carbohydrate metabolism, as well as the stimulation of the renin-angiotensin-aldosterone system (RAAS) and of the sympathetic nervous system (SNS) (6). In hemodialysis patients (HD) the recommended sodium intake is similar to that of the general population $(7,8)$. The current clinical guidelines recommend to limit the dietary sodium intake in dialysis patients up to $5 \mathrm{~g}$ /day $(2 \mathrm{~g}$ or $85 \mathrm{mmol})(9,10)$.

Sodium homeostasis. Sodium is almost completely absorbed in the proximal ileum, the rest being absorbed in the distal colon. Sodium is filtered up to $95 \%$ in urine, then $80 \%$ is reabsorbed; $4.5 \%$ is eliminated through feces and $0.5 \%$ through sweating.

The level of plasma and extracellular compartment sodium is maintained by the body through a series of mechanisms: Changes in the renal blood flow, carbonic anhydrase activity, the RAAS, the antidiuretic hormone (ADH), and through the activity of other steroid hormones whose concentration is monitored by the anterior pituitary gland (3). In hemodialysis patients, sodium balance and fluid balance are maintained through the salt ingestion in between dialysis sessions, the sodium in excess being eliminated through dialysis and residual diuresis (1). The largest amount of sodium is eliminated through ultrafiltration (convection 78\%) and a small percentage (22\%) through diffusion in hemodialysis (11).

\section{Disorders of sodium balance}

Hypernatremia. The increase of $\mathrm{Na}^{+}$level has a pressor effect through the activation of the sympathetic flow in the medullary vasomotor center, with the increase of angiotensin II activity, on one hand, and reduction in nitric oxide biodisponibility, on the other. The consequence of these changes is an increase of the vascular stiffness and of the blood pressure (BP). Both hypertension and hyperhydration lead to the left ventricular hypertrophy and the onset of cardiovascular disease, which are the main causes of mortality in dialysis patients (12). A significant percentage of the dialysis patients are diabetic and over $50 \%$ of them present high BP. In diabetic patients, the most important causes of high BP are: Fluid and salt retention, RAAS and SNS activation, oxidative stress and endothelial dysfunction (13). Oxidative stress is an important element initiating diabetic microvascular complications, including diabetic kidney disease (14-16). A study on hemodialysis patients suggests that xanthine oxidoreductase (XOR) should be considered as an important target in the attempt to reduce oxidative stress in the context of diabetic kidney disease (17).

Uric acid is both a marker for the cardiovascular risk, and an independent risk factor for the onset of high BP and cardiac insufficiency, being proved that hyperuricemia produces endothelial dysfunction, inflammation and the activation of the renine-angiotensin-aldosteron system $(18,19)$.

HBP affects a high percentage of patients, according to current studies, which take into account the entire population of hemodialysis patients. Thus, over $50 \%$ of the HD patients suffer from high BP in different stages. In a recent study including 123 patients undergoing hemodialysis at Emergency University Hospital Bucharest, $87 \%$ of them had hypertension (20). It should be mentioned that HBP, anemia and vascular calcifications (VC) are the main causes of cardiovascular mortality (20-22). There are no clearly established target BP values in hemodialysis population; it is, nevertheless, recommended that BP should not exceed $140 / 90 \mathrm{mmHg}$ pre-dialysis and $130 / 180 \mathrm{mmHg}$ post-dialysis (the recommendation has no strong evidence) (23). Studies 
Table I. Hypertension in hemodialysis patients: Recommendations (23).

\section{Reassessment of DW}

- Weight loss until reaching DW should not exceed 1-2 kg a week

- Additional dialysis sessions may be useful to reach DW

2. Salt intake restricted to $5 \mathrm{~g} /$ day

3. The interdialytic weight gain should be $1 \mathrm{~kg}$ maximum during the week and $1.5-2 \mathrm{~kg}$ at the weekend

4. Avoiding sodium profiles and the use of high sodium content dialysate

DW, dry weight.

have shown that the lowest mortality is associated with BP values between 140-160/70-90 $\mathrm{mmH}$ and the highest, with BP values $>180 / 100 \mathrm{mmHg}(24-26)$.

In dialysis patients, the increased fluid retention between two consecutive dialysis sessions is associated with a high risk of general and cardiovascular mortality (27).

The need of fluid intake restriction is emphasized in daily practice, but it is generally omitted to instruct patiens about the importance of sodium intake restriction, which is essential in the dialysis patient's diet and without which fluid intake restriction is inefficient $(28,29)$. In chronic dialysis patients, the BP is influenced by many factors, such as: Hyperhydration, arterial stiffness associated with atherosclerosis, the decrease of NO formation connected to salt retention, SNS hyperactivity, RAAS activation, the presence of other vasoconstrictor agents, insufficient vasodilator factors, therapy of erythropoiesis-stimulating agents or genetic predisposition (23). Table I presents specific recommendations for HD patients to keep BP within accepted limits.

Antihypertensive medication must be associated in patients who reached the dry weight (DW) but are still hypertensive. RAAS blockers are the initial medication, especially in diabetic and/or cardiac failure patients. The angiotensin-converting-enzyme inhibitors (ACE inhibitors) are dialyzable, but Fosinopril (which has a renal and billiary elimination) is excepted. As a result, Fosinopril or sartan therapy (angiotensine receptors blockers) is recommended in patients with intradialytic hypertension (30).

Beta-blockers may represent an option in the patients with ischemic heart disease and cardiac failure. Taking into account that beta-blockers are hydrosoluble and are dialyzable, an extra dose should be administered following dialysis (30).

Calcium channel blockers are not dialyzed and can safely be used (30).

Hyponatremia. The imbalance of sodium levels may cause intradialytic cardiovascular instability, as well as interdialytic hyperhydration and high BP.

Intradialytic cardiovascular instability represents a problem because of the ageing of the hemodialysis population and the increase of diabetic patients with cardiovascular co-morbidities. Studies show that intradialytic hypotension (IDH) occurs in $20-30 \%$ of the dialysis sessions and is
Table II. IDH prevention in chronic hemodialysis patients: Recommendations (23).

Reassessment of DW

Maintaining the interdialytic excess weight under $3 \%$ of the DW

Avoiding the administration of antihypertensive medication before dialysis and food intake during dialysis

Correcting anemia

Measures for performing the HD session

- Use of bicarbonate dialysate

- Use of high calcium content dialysate (if possible)

- Applying the ultrafiltration or sodium profiling in some patients

IDH, intradialytic hypotension; DW, dry weight; HD, hemodialysis.

associates with the cardiovascular mortality (31). A recent study, on 112,013 hemodialysis patients, followed for a 5-year period, showed that IDH is common in chronic dialysis patients and is associated with increased mortality (32).

IDH has an impact on quality of life in dialysis patients, increases the treatment cost, influences the time and effort of the medical staff and it is associated with the increased cardiovascular and cerebrovascular morbidity and mortality, and with mesenteric ischemia $(33,34)$.

The patient may be asymptomatic or may present the following: Muscle cramps, nausea, vomiting, severe physical asthenia. IDH is especially symptomatic in case of women, the elderly, patients with heart diseases, diabetes or vegetative neuropathy (35). Table II summarizes the current recommendations to prevent IDH.

Dialysate sodium concentration. Ideally, the level of sodium in the dialysate is established according to the patient's pre-dialysis blood sodium. Scientific evidence shows that maintenance of the dialysate $\mathrm{Na}^{+}$between $134-138 \mathrm{mEq} / 1$, both in standard and night dialysis, causes the decrease of interdialytic body weight gain (IDBWG) and of pre-dialysis systolic pressure, without increased occurrence of intradialytic adverse events (36).

$\mathrm{Na}^{+}$concentration in the dialysate lower than plasma $\mathrm{Na}^{+}$ level causes rapid dialysis of the osmotic substances (urea, glucose etc.), the decreased of the osmotic pressure and the refilling of the vascular bed in the extracellular compartment, producing muscle cramps and IDH. These complications lead to inadequte ultrafiltration, interdialytic body weight gain (IDBWG) over 3\% and failure to reach DW, associated with an increased mortality risk $(31,37,38)$.

$\mathrm{Na}^{+}$in the dialysate over the plasma levels of $\mathrm{Na}^{+}$, prevents the refilling of the vascular bed by maintaing osmotic pressure with intradialytic hemodynamic stability, but there is a risk of positive sodium balance, with HBP, thirst and increased fluid intake, which leads to high interdialytic body weight gain. IDBWG requires: The increase of the ultrafiltration rate and of the dialysis duration, and more frequent sessions to attain DW. High body weight gain along with increased ultrafiltration 
Table III. Na concentration in the dialysate and the impact of its variations: Summary of recommendations $(27,36,37,39,40)$.

\begin{tabular}{|c|c|c|c|c|}
\hline Electrolyte & $\begin{array}{l}\text { Recommended } \\
\text { value } \\
\text { (in dialysate) }\end{array}$ & $\begin{array}{c}\text { Variations: } \\
\text { Physiopathologic } \\
\text { consequences }\end{array}$ & $\begin{array}{c}\text { Variations: } \\
\text { Clinical consequences }\end{array}$ & $\begin{array}{l}\text { Variations: Effects } \\
\text { following hemodialysis }\end{array}$ \\
\hline $\mathrm{Na}^{+}$ & $134-138 \mathrm{mEq} / \mathrm{l}$ & $\begin{array}{l}\mathrm{Na}^{+} \text {concentration in the } \\
\text { dialysate under the level } \\
\text { of plasma } \mathrm{Na}^{+} \\
\text {The decrease of osmotic } \\
\text { substances in plasma } \\
\text { (urea, glucose, etc) which } \\
\text { dialyze rapidly will lead to } \\
\text { a fall in the osmotic presure } \\
\text { and refilling of the vascular } \\
\text { bed in the extracellular } \\
\text { compartment } \\
\mathrm{Na}^{+} \text {concentration in the } \\
\text { dialysate over the level of } \\
\text { plasma Na } \\
\text { Maintaining of the osmotic } \\
\text { pressure prevents the } \\
\text { refilling of the vascular bed }\end{array}$ & $\begin{array}{l}\mathrm{Na}^{+} \text {concentration in the } \\
\text { dialysate under the level } \\
\text { of plasma } \mathrm{Na}^{+} \text {muscle } \\
\text { cramps intradialytic } \\
\text { hypotension } \mathrm{Na}^{+} \\
\text {concentration in the } \\
\text { dialysate over the level } \\
\text { of plasma } \mathrm{Na}^{+} \\
\text {Intradialytic hemodynamic } \\
\text { stability }\end{array}$ & $\begin{array}{l}\mathrm{Na}^{+} \text {concentration in the } \\
\text { dialysate under the level of } \\
\text { plasma } \mathrm{Na}^{+} \text {inadequate } \\
\text { ultrafiltration } \\
\text { Interdialytic weight excess } \\
\text { over }>3 \% \text { of the DW and the } \\
\text { inability to reach DW } \\
\text { Increased risk of mortality } \\
\mathrm{Na}^{+} \text {concentration in the dialysate } \\
\text { over the level of plasma } \mathrm{Na}^{+} \\
\mathrm{Risk} \text { of: } \mathrm{HBP} \text {, thirst and increased } \\
\text { fluid intake } \\
\text { Interdialytic weight excess }\end{array}$ \\
\hline
\end{tabular}

$\mathrm{Na}^{+}$, sodium; DW, dry weight; HBP, high blood pressure.

rate are associated with an increased risk of the general and cardiovascular mortality $(27,39,40)$.

Sodium profile (high $\mathrm{Na}^{+}$level at the HD onset and low in the last hours) is recommended in certain patient groups, especially for the patients with IDH, cramps, severe uremia and hemodynamic instability; $\mathrm{Na}^{+}$modulation is not recommended for patients with hypernatremia or intradialitic hypertension (41).

Adjustment of the $\mathrm{Na}^{+}$balance will be mentioned individually on each patient's prescription. A summary of recommended $\mathrm{Na}^{+}$concentration in the dialysate and the efects of these variations are presented in Table III.

\section{Potassium $\left(\mathbf{K}^{+}\right)$}

Biological role of potassium. Potassium is the main cation in the intracellular space, playing an essential role in the maintenance of the resting membrane potential, neuromuscular function, the regulation of the myocardial contractility, the intracellular fluid and acid-base balance, the maintenance of the cellular volume, cellular increase, DNA and cellular protein synthesis and enzymatic function (42).

The normal values of the serum potassium in the general population are: $3.5-5 \mathrm{mEq} / 1$ (3.6-4.8 $\mathrm{mmol} / \mathrm{l})$; in dialysis patients the values considered normal are higher. There are many studies in the medical literature which show the relationship between potassium values and mortality of the dialysis patients. A study on 2134 hemodialysis patients found the smallest risk of sudden death in patients with potassium level under $5.1 \mathrm{mEq} / \mathrm{l}$. Death risk was enhanced by the increase of $\mathrm{K}^{+}$levels in these patients (43).
Another study on 81.013 chronic hemodialysis patients emphasized that $\mathrm{K}^{+}$values between 4.6 and $5.3 \mathrm{mEq} / 1$ are associated to the lowest incidence of general mortality (44).

A study on a multinational cohort of 55,183 hemodialysis patients (DOPPS) confirms these findings, showing that the lowest death risk occurs in patients with pre-dialysis $\mathrm{K}^{+}$levels between 4 and $5.5 \mathrm{mEq} / \mathrm{l}$; the death and arrhythmia risk significantly increases if $\mathrm{K}^{+} \geq 5.6$ and diminishes at under $4 \mathrm{mEq} / \mathrm{l}$ potassium levels (after the statistical assessment of malnutrition indicators) (45).

Potassium homeostasis. Potassium is highly soluble and disperses rapidly in water in the upper digestive tract, being absorbed up to $90 \%$ (46). The daily potassium intake is estimated to be $50-100 \mathrm{mmol} /$ day (47). A lower potassium intake (2-3 mg/day) is recommended to hemodialysis patients (48).

Potassium is eliminated mainly through the kidneys (90\%) in about 6-12 h and only a small amount (10\%) through the colon (47). Potassium undergoes glomerular filtration, $65 \%$ is reabsorbed in the proximal tubule and is secreted in the urine in the distal and collecting tubules. Renal potassium excretion is influenced by $\mathrm{Na}^{+}$level in the distal tubule, RAAS activation, vasopressine, dietary potassium intake, acid-base balance, urinary flow in the distal nephron and levels of serum potassium (42).

The maintenance of the intra- and extracellular potassium balance is stimulated by a series of factors. Thus, potassium entry to the cell is activated by insulin, catecholamines and the anabolic status. The opposite process, $\mathrm{K}^{+}$exit in the extracellular space, occurs during metabolic acidosis, hyperosmolarity, nonselective beta-blockers and alpha 1 receptor stimulation. 
Aldosterone plays an important role in the maintenance of the potassium balance; aldosterone modulates the membrane ATPase membrane in the distal nephron (distal and collecting tubules), with increased $\mathrm{K}^{+}$excretion. Aldosterone also influences colon and salivary $\mathrm{K}^{+}$excretion (49). Stimulation of the aldosterone secretion is mainly due to angiotensin II and increased serum levels of potassium (50).

Disorders of potassium balance. Diskalemia is frecquently found in the dialysis patients and associates with an increased mortality (47).

Hyperkalemia. Hyperkalemia is more common than hypokalemia in the dialysis population and increases the death risk through arrhythmias; $24 \%$ of hemodialysis patients can suffer from hyperkalemia which requires emergency HD (51).

Hyperkalemia related mortality was estimated at 3.1 per 1,000 patient/year (52).

The correlation between hyper- and hypokalemia and the risk of general and cardiovascular mortality in the chronic hemodialysis patients was demonstrated by previous studies $(53,54)$ and confirmed by the recent ones. This association later diminished considerably through statistical regression analysis, taking into account the fact that the severe hypokalemia is commonly found in the patients with severe malnutrition and generally present with other pathologies, as well $(44,45)$.

Considering the fact that potassium excretion takes place mainly in the kidneys, dialysis patients are at a high risk of hyperkalemia, especially patients who have a series of supplimentary factors, such as: Insulin deficiency, medication which interferes with potassium renal excretion such as aldosterone antagonists, angiotensin II converting enzyme inhibitors and/or AT II receptor blockers (55). Chronic hemodialysis patients develop adaptive mechanisms to compensate the decrease of potassium renal excretion. In these patients colonic elimination of potassium is 2-3 times higher than in patients with normal renal function $(56,57)$. In the first category of patients, the maintenance of the potassium balance is achieved through the alteration of intra- and extracellular distribution. Insulin stimulates $\mathrm{K}^{+}$entry inside the cells; dialysis patients who do not feed properly for a longer periods of time, presents hyperkalemia (58).

Secondary hyperparathyroidism decreases $\mathrm{K}^{+}$entry inside the cell through increased intracellular $\mathrm{Ca}^{2+}$, which supresses the oxidative metabolism and the cellular ATP production and reduces the $\mathrm{Na}^{+}-\mathrm{K}^{+}$- ATP ase activity (59).

Extracellular hypertonicity, which is usually found in the hyperglycemic diabetic patients (60) or in patients who received hypertonic solutions causes hyperkalemia through $\mathrm{K}^{+}$ exit of the cells through insulin deficiency (61).

The excess of physical activity and hemolysis cause the release of a large amounts of $\mathrm{K}^{+}$in the extracellular space. Table IV summarises the causes of hyperkalemia in the chronic dialysis patients.

A minor $\mathrm{K}^{+}$variation in the extracellular compartment causes important changes in the resting membrane potential (RMP) and affects the myocardial and the neuromuscular cells; decreased RMP can lead to fatal arrhythmias. The first sign of hyperkalemia on the ECG are the tenting of the T wave. ECG
Table IV. Causes of hyperkalemia in chronic hemodialysis patients $(55,62-64)$.

1. Increased interdialysis nutritional $\mathrm{K}^{+}$intake

2. Lack of residual renal function (the major route of $\mathrm{K}^{+}$ excretion in the general population)

3. Decreased $\mathrm{K}^{+}$clearance during dialysis

4. Hypoaldosteronism

5. Metabolic acidosis

6. Blood transfusions

7. Abnormal colonic $\mathrm{K}^{+}$secretion

8. Administration of certain drugs:

- COX 1 and 2 inhibitors

- Beta-blockers

- Converting enzyme inhibitors

- Potassium-sparing diuretics

- Digoxin

- Cyclosporines

- Tacrolimus

- Ketoconazole

- Potassium-containing drugs

$\mathrm{K}^{+}$, potassium; COX, cyclooxygenase.

Table V. Chronic hemodialysis patients: causes of hypokalemia $(71,72)$.

1. Low $\mathrm{K}^{+}$nutritional intake

2. Malnutrition

3. Chronic diarrhea

4. Iatrogenic: Administration of mineralocorticoids or excess of potassium-binding resins

changes then progress rapidly, together with increased $\mathrm{K}^{+}$level: QRS complex enlargement, progressive atrioventricular block, idioventricular rhythm, then the appearance of the sinewave, ventricular fibrillation and, finally, asystole (65). Serum $\mathrm{K}^{+}$and ECG changes do not always correlate closely (66).

Patients with hyperkalemia may have neuromuscular symptoms like: Paresthesia, muscular weakness in the limbs followed by de-symmetrical flaccid paralysis of extremities, with ascending development and involvement of respiratory muscles. Hyperkalemia does not usually affect cranial nerves (47).

Hemodialysis is the treatment of choice in chronic dialysis patients with severe hyperkalemia. $70-150 \mathrm{mEq}$ of potassium is eliminated quickly through HD (67). Potassium is $85 \%$ removed through diffusion and $15 \%$ through convection during HD $(68,69)$.

In order to avoid a subsequent event, it is recommened to investigate the cause of hyperkalemia: Dietary assessment, medication, acidosis. The $\mathrm{K}^{+}$intake will be reduced to 40-70 $\mathrm{mEq} /$ day, the treatment including potassium-binding resins will be reassessed, acidosis will be monitored by sodium bicarbonate administration, which induces kaliuresis 
Table VI. Special recommendations concerning the amount of electrolytes in the dialysate $(36,41,43,74,75,81)$.

\begin{tabular}{|c|c|c|c|}
\hline Electrolyte & Normal serum value & $\begin{array}{l}\text { Recommended value } \\
\text { in the dialysate }\end{array}$ & Special considerations \\
\hline $\mathrm{Na}^{+}$ & 135-145 mEq/1 & $134-138 \mathrm{mEq} / \mathrm{l}$ & $\begin{array}{l}\mathrm{Na}^{+} \text {-profile indicated for: } \\
\text { - Patients with IDH } \\
\text { - Patients with muscle cramps } \\
\text { - Patients with hemodynamic instability } \\
\mathrm{Na}^{+} \text {-profile contraindicated for: } \\
\text { - Patients with hypernatremia } \\
\text { - patients with intradialysis hypertension }\end{array}$ \\
\hline $\mathrm{K}^{+}$ & $3.5-5 \mathrm{mEq} / 1$ & $2-3 \mathrm{mEq} / 1$ & $\begin{array}{l}\text { Recommendations: } \\
\text { - Use of dialysate containing } 2 \mathrm{mEq} / 1 \mathrm{~K}^{+} \text {in patients with } \\
\text { serum } \mathrm{K}^{+} \text {of } 4-6 \mathrm{mEq} / 1 \text { at the beginning of the dialysis } \\
\text { - Use of dialysate containing } 3 \mathrm{mEq} / 1 \mathrm{~K} \text { in patients with } \\
\text { normal serum } \mathrm{K}^{+} \text {before dialysis }\end{array}$ \\
\hline $\mathrm{Ca}$ & $8.4-9.5 \mathrm{mg} / \mathrm{dl}$ & $\begin{array}{l}2.5-3 \mathrm{mEq} / 1 \\
(1.25-1.75 \mathrm{mmol} / \mathrm{l})\end{array}$ & Adjusted $\mathrm{Ca}$ in the dialysate according to patient's profile \\
\hline
\end{tabular}

$\mathrm{Na}^{+}$, sodium; IDH, intradialytic hypotension; $\mathrm{K}^{+}$, potassium; $\mathrm{Ca}$, calcium.

and supports intracellular $\mathrm{K}^{+}$. These patients can also be given potassium - binding resins such as Kayexalate sau Kalimate, combined with sorbitol in small doses, daily or every other day, to avoid constipation (70).

Hypokalemia. Hypokalemia is defined as a potassium value below $3.5 \mathrm{mEq} / 1$. It is less frequent than hyperkalemia, but findings differ among the dialysis facilities. Table $\mathrm{V}$ shows the causes of hypokalemia found in chronic hemodialysis patients.

Clinical manifestations are due to the change of resting membrane potential of cardiac and muscle cells. Symptomatology varies from neuromuscular astenia to arrhythmia and cardiac arrest. Fatal rhythm disturbances are almost exclusively found in patients with underlying cardiac disease or patients taking digitalis (42).

In hypokalemia, the ECG shows: Flattened T wave, inverted ST, U wave, prolonged QT interval and, finally, ventricular arrhythmia causing cardiac arrest (73).

Dialysate potassium concentration. $\mathrm{K}^{+}$level in the dialysate must be individually prescribed for every patient. Over the past years it has been recommended to avoid very small amounts of $\mathrm{K}^{+}$in the dialysate, preventing excessive decrease of serum $\mathrm{K}^{+}$: Thus, a dialysate containing $2 \mathrm{mEq} / \mathrm{l}$ de $\mathrm{K}^{+}$is recommended in patients with $4-6 \mathrm{mEq} / 1 \mathrm{~K}^{+}$serum at the beginning of dialysis (74) and a dialysate containing $3 \mathrm{mEq} / \mathrm{K} \mathrm{K}$ in patients with normal pre-dialysis serum $\mathrm{K}^{+}$levels (75). Hypokalemia treatment can be oral or parenteral. There are four oral types of substances: Potassium chloride, potassium phosphate, potassium bicarbonate and potassium citrate. Potassium phosphate is recommended in the patients with hypokalemia and hypophosphatemia, and potassium bicarbonate in those with metabolic acidosis and hypokalemia. Potassium chloride will be administered in all other circumstances. Intravenuous administration of the potassium preparations is recommended in severe hypokalemia associated with cardiorespiratory instability. Infusion rate should not exceed $20 \mathrm{mmol} / \mathrm{h}$ during intravenuous administration, so as to avoid iatrogenic hypokalemia (42).

\section{Calcium $\left(\mathrm{Ca}^{2+}\right)$}

Biological role of calcium. Calcium is an essential element, found in two forms in the body: In bones and in teeth, as hydroxiapatite $\left(\mathrm{Ca}_{10}\left[\mathrm{PO}_{4}\right]_{6}[\mathrm{OH}]_{2}\right)(>99 \%)$, ensuring tissue hardness, and in plasma (about $1 \%$ ), where it can be in active, ionized form (50\%) which diffuses inside the cells, and bound to albumines or in calcium citrate and phosphate complexes (50\%) (76-78).

The calcium in the circulatory system, the extracellular compartment, muscles and other tissues has a key role in several biological processes, such as: Myocardial contractility and conduction, regulation of the vascular smooth muscle tone and vasomotricity, controle of the neuromuscular excitability and nerve conduction, muscle contraction, a role in the blood coagulation and bone mineralization (control of PTH, calcitonine and vitamin $\mathrm{D}_{3}$ production), the transmission of the intracellular signals and hormone secretion and also in the activation of the oxidative stress in myocardium and brain (79). Bones are the main calcium storages and the source for these metabolic processes, through bone remodelling processes (80).

Calcium homeostasis. The normal values in the general population are: Ionized calcium $=4.5-5.6 \mathrm{mg} / \mathrm{dl}(2.2-2.8 \mathrm{mEq} / \mathrm{l})$, total calcium in the blood (calcemia) $=9-11 \mathrm{mg} / \mathrm{dl}$. In hemodialysis patients, K-DOQI guidelines recommends: Target for serum calcium 8.4-9.5 mg/dl and for dialysate: Ca-2.5-3 mEq/1 (1.25-1.5 mmol/l) $(23,81)$.

Calcium mainly comes from nutriments and dietary supplements, and only a small amount from water, depending on the residential area. The total amount varies between 0.918 and $1.296 \mathrm{~g} /$ day, on average (82). 
The oral calcium intake in the dialysis patients must be maximum $2 \mathrm{~g} /$ day $(500 \mathrm{mg} /$ day through diet and $1.5 \mathrm{~g} / \mathrm{day}$ through calcium phosphate binders) (83). In the dialysis patients who need calcium phosphate binders, the doses should be decreased (81).

Calcium is absorbed in the intestinal mucosa cells, by active (transcellular) and passive (paracellular) transport mechanisms. Calcium active transport depends on calcitriol action and the intestinal vitamin D receptor (VDR).

Calcium is mainly excreted through urine and feces. Calcium excretion in urine depends on the calcium glomerular filtration (approximately 98\%) and on the reabsorption in the renal tubules, through active and passive processes. Over $70 \%$ of the calcium filtered by renal glomeruli is passively reabsorbed by the proximal tubule; the calcium active transport occurs at the level of the ascending limb of the loop of Henle. At the distal tubule, calcium active transport is regulated by calcitriol and estradiol. Calcium transport is passive at the level of collecting tubules (84).

Calcium balance is achieved through complex hormone mechanisms, acting at intestinal, renal, and bone levels, through several substances: The parathyroid hormone (PTH), 1.25-dihydroxyvitamin D (calcitriol), fibroblast growth factor 23, calcitonine and estrogens (85).

The decrease of serum $\mathrm{Ca}^{2+}$ stimulates PTH production, which acts at the ascending limb of the Henle loop, the distal tubule and collecting tubules, with increased $\mathrm{Ca}^{2+}$ reabsorption. PTH also stimulates ostoclastes with increased bone resorption and $\mathrm{Ca}^{2+}$ reabsorption.

Calcitriol increases serum $\mathrm{Ca}^{2+}$ by acting on the gastrointestinal tract, bones and kidneys. Calcitonine is a peptide hormone, produced and released by the thyroid parafollicular cells (' $\mathrm{C}$ cells') in response to the increase of serum calcium and stimulates the osteoblasts, with increased $\mathrm{Ca}^{2+}$ deposition in the bones. Calcitonine inhibits $\mathrm{Ca}^{2+}$ reabsorption in the kidneys and intestines, with the increase of serum Ca (86).

The major factors causing the increase and the decrease of the serum calcium in hemodialysis patients are: The secondary hyperparathyroidism treatment with vitamin D and its analogues, the calcimimetics and administration of $\mathrm{Ca}^{2+} / \mathrm{Mg}^{2+}$ phosphate binders, the excessive calcium intake or $\mathrm{Ca}^{2+}$ concetration in the dialysate during hemodialysis (87).

Disorders of calcium balance. Intradialysis and immediate post-dialysis serum $\mathrm{Ca}^{2+}$ changes have mainly hemodynamic effects, by influencing the heart muscle and the peripheral vascular tone.

Hypercalcemia. The relationship between hypercalcemia and mortality has been demonstrated in a number of studies $(88,89)$. Hypercalcemia increases mortality through predisposition to arrhythmia, high BP (90) and VC. Dialyses patients with vascular or valvular calcification present a higher risk (90).

Studies have emphasized the strong correlation between valvular and $\mathrm{VC}$ and bone diseases in the hemodialysis patients (88) and also the high incidence of VC since the predialytic stages of CKD is strongly correlated with age, cardiovascular comorbidities, osteoporosis and decrease of GFR (91).
Hypocalcemia. Hypocalcemia occurs in the dialysis patients because of the use of calcimetics, non-calcium phosphates binders and low level $\mathrm{Ca}^{2+}$ dialysate, as well as dietary $\mathrm{Ca}^{2+}$ intake $(23,89,92)$.

Calcium values of $<9$ and $>10 \mathrm{mg} / \mathrm{dl}$ are associated to increased mortality (93).

Severe hypocalcemia increases mortality through the predisposition to develop arrhythmias (94).

Dialysate calcium concentration. KDIGO 2017 guidelines recommend a calcium concentration between 1.25 and $1.50 \mathrm{mmol} / \mathrm{l}(2.5$ and $3.0 \mathrm{mEq} / \mathrm{l})$ in the dialysate (81).

$\mathrm{Ca}$ concentration in the dialysate has both short-term and long-term effects. Increased calcium in the dialysate (1.75 mmol/l) influences PTH control and hemodynamic instability, but contributes to accelerated VC and bone and mineral imbalance, with adynamic bone (89).

A high level of $\mathrm{Ca}^{2+}$ in the dialysate $(1.75 \mathrm{mmol} / \mathrm{l})$ is associated to an increased sympathetic activity and a better intradialysis hemodynamic stability (95). Decreased $\mathrm{Ca}^{2+}$ in the dialysate $(1.25 \mathrm{mmol} / \mathrm{l})$ accelerates the bone turnover and the hemodynamic instability. Patients receiving dialysate containing $\mathrm{Ca}^{2+} 1.25 \mathrm{mmol} / 1$ experience arrhythmia and sudden cardiac arrest more often $(96,97)$, probably because of increased QT interval (98). Table VI presents special recommendations for chronic hemodialysis patients concerning the amount of electrolytes in the dialysate.

To avoid and treat these imbalances each patient must be individually assessed and the dialysis parameters must be prescribed accordingly.

\section{Conclusions}

Dyselectrolytemia is a group of dialysis complications with immediate and long-term effects, which increase the mortality rate of hemodialysis patients through cardiovascular complications. The ionic profile of the dialysis patients must be monitored, and the treatment must be individualized and adapted. The clinician must pay increased attention to the patient's dietary hygiene, to the drug therapy and to the dialysis parametres in chronic dialysis patient management.

\section{Acknowledgements}

Not applicable.

\section{Funding}

No funding was received.

\section{Availability of data and materials}

All data generated or analyzed during this study are included in this published article.

\section{Authors' contributions}

DT, MDT, AEBS, DGB, AT, OS, IAV, AM, PCC, CIC, ME, DM and DI designed the study, wrote the manuscript, performed the literature research and selected the included studies. DT, 
MDT, AEBS, DGB, AT, OS, IAV, AM, PCC, CIC, ME, DM and DI critically revised the manuscript. All authors read and approved the final manuscript. The contributions of all the authors to this review are greatly valued and appreciated.

\section{Ethics approval and consent to participate}

Not applicable.

\section{Patient consent for publication}

Not applicable.

\section{Competing interests}

The authors declare that they have no competing interests.

\section{References}

1. Flanigan MJ: Role of sodium in hemodialysis. Kidney Int Suppl 58 (Suppl 76): S72-S78, 2000.

2. Suhail $\mathrm{M}: \mathrm{Na}^{+}, \mathrm{K}^{+}$-ATPase: Ubiquitous multifunctional transmembrane protein and its relevance to various pathophysiological conditions. J Cli Med Res 2: 1-17, 2010.

3. Adrogue HJ and Madias NE: Hypernatremia. N Engl J Med 342: 1493-1499, 2000.

4. De Luca L, Klein L, Udelson JE, Orlandi C, Sardella G, Fedele F and Gheorghiade M: Hyponatremia in patients with heart failure. Am J Cardiol 96: 19-23, 2005.

5. Papacocea MT, Badarau IA, Radoi M and Papacocea IR: The predictive role of biochemical plasma factors in patients with severe traumatic brain injuries. Rev Chim Buchar 70: 1754-1757, 2019.

6. Balan DG, Stroescu AEB, Tanasescu MD, Diaconescu A, Raducu L, Mihai A, Tanase M, Stanescu II and Ionescu D: Nutritional intervention in patients with diabetic renal diseasee. A brief presentation. Rev Chim Buchar 69: 3178-3182, 2018.

7. Maduell F and Navarro V: Dietary salt intake and blood pressure control in haemodialysis patients. Nephrol Dial Transplant 15: 2063, 2000.

8. Lambie SH, Taal MW, Fluck RJ and McIntyre CW: Online conductivity monitoring: Validation and usefulness in a clinical trial of reduced dialysate conductivity. ASAIO J 51: 70-76, 2005.

9. Fouque D, Vexnnegoor M, ter Wee P, Wanner C, Basci A, Canaud B, Haage P, Konner K, Kooman J, Martin-Malo A, et al: EBPG guideline on nutrition. Nephrol Dial Transplant 22 (Suppl 2): ii45-ii87, 2007.

10. Kutlugün AA, Arici M, Yıldırım T, Turgut D, Yılmaz R, Altındal M, Altun B, Erdem Y, Yasavul U and Turgan C: Daily sodium intake in chronic kidney disease patients during nephrology clinic follow-up: An observational study with 24-hour urine sodium measurement. Nephron Clin Pract 118: C361-C366, 2011.

11. Santos SFF and Peixoto AJ: Sodium balance in maintenance hemodialysis. Semin Dial 23: 549-555, 2010.

12. Silberberg JS, Barre PE, Prichard SS and Sniderman AD: Impact of left ventricular hypertrophy on survival in end-stage renal disease. Kidney Int 36: 286-290, 1989.

13. Balcangiu-Stroescu AE, Tanasescu MD, Diaconescu AC, Raducu L, Balan DG, Mihai A, Tanase M, Stanescu II and Ionescu D: Diabetic nephropathy: A concise assessment of the causes, risk factors and implications in diabetic patients. Rev Chim Buchar 69: 3118-3121, 2018.

14. Epingeac ME, Gaman MA, Diaconu C, Gad M and Gaman AM: The evaluation of oxidative stress in obesity. Rev Chim Buchar 70: 2241-2244, 2019.

15. Diaconu C: Treatment of diabetes in patients with heart failure. In: The 3rd International conference on interdisciplinary management of diabetes mellitus and its complications - diabetes mellitus in internal medicine, INTERDIAB 2017 Proceedings. Serafinceanu C, Negoita O and Elian V (eds.) Niculescu, Bucharest pp170-177, 2017.
16. Savu O, Ionescu-Tirgoviste C, Atanasiu V, Gaman L, Papacocea R and Stoian I: Increase in total antioxidant capacity of plasma despite high levels of oxidative stress in uncomplicated type 2 diabetes mellitus. J Int Med Res 40: 709-716, 2012.

17. Totan A, Balcangiu-Stroescu AE, Melescanu Imre M, Miricescu D, Balan DG, Stanescu II, Ionescu D, Timofte D, Tanasescu MD and Greabu M: XOR-possible correlations with oxidative stress and inflammation markers in the context of diabetic kidney disease. Rev Chim Buchar 70: 1396-1398, 2019.

18. Timofte D, Mandita A, Balcangiu-Stroescu AE, Balan DG, Raducu L, Tanasescu MD, Diaconescu AC, Dorin D, Cosconel CI, Stoicescu SM, et al: Hyperuricemia and cardiovascular diseases - clinical and paraclinical correlations. Rev Chim Buchar 70: 1045-1046, 2019.

19. Gaman MA, Dobrica EC, Pascu EG, Cozma MA, Epingeac ME, Gaman AM, Pantea Stoian A, Bratu OG and Diaconu CC: Cardiometabolic risk factors for atrial fibrillation in type 2 diabetes mellitus: Focus on hypertension, metabolic syndrome and obesity. J Mind Med Sci 6: 157-161, 2019.

20. Balcangiu-Stroescu AE, Tanasescu MD, Diaconescu AC, Raducu L, Constantin AM, Balan DG, Tharmure V and Ionescu D: Cardiovascular comorbidities, inflammation and serum albumin levels in a group of hemodialysis patients. Rev Chim Buchar 69: 926-929, 2018.

21. Wright $\mathbf{J}$ and Hutchison A: Cardiovascular disease in patients with chronic kidney disease. Vasc Health Risk Manag 5: 713-722, 2009.

22. Hemodialysis Adequacy 2006 Work Group: Clinical practice guidelines for hemodialysis adequacy, update 2006. Hemodialysis adequacy 2006 work group. Am J Kidney Dis 48 (Suppl 1): S2-S90, 2006.

23. Agarwal R: Hypertension and survival in chronic hemodialysis patients - past lessons and future opportunities. Kidney Int 67: $1-13,2005$.

24. Lacson E Jr and Lazarus JM: The association between blood pressure and mortality in ESRD - not different from the general population? Semin Dial 20: 510-517, 2007.

25. Peixoto AJ and Santos SF: Blood pressure management in hemodialysis: What have we learned? Curr Opin Nephrol Hypertens 19: 561-566, 2010.

26. Kalantar-Zadeh K, Regidor DL, Kovesdy CP, Van Wyck D, Bunnapradist S, Horwich TB and Fonarow GC: Fluid retention is associated with cardiovascular mortality in patients undergoing long-term hemodialysis. Circulation 119: 671-679, 2009.

27. Tomson CR: Advising dialysis patients to restrict fluid intake without restricting sodium intake is not based on evidence and is a waste of time. Nephrol Dial Transplant 16: 1538-1542, 2001.

28. K/DOQI clinical practice guidelines for cardiovascular disease in dialysis patients. Am J Kidney Dis 45: 1-153, 2005.

29. Mandita A, Timofte D, Balcangiu-Stroescu AE, Balan DG, Raducu L, Tanasescu MD, Diaconescu AC, Dorin D, Cosconel CI, Stoicescu SM, et al: Treatment of high blood pressure in patients with chronic renal disease. Rev Chim Buchar 70: 993-995, 2019.

30. Stefánsson BV, Brunelli SM, Cabrera C, Rosenbaum D, Anum E, Ramakrishnan K, Jensen DE and Stalhammar N-O: Intradialytic hypotension and risk of cardiovascular disease. Clin J Am Soc Nephrol 9: 2124-2132, 2014.

31. Chou JA, Streja E, Nguyen DV, Rhee CM, Obi Y, Inrig JK, Amin A, Kovesdy CP, Sim JJ and Kalantar-Zadeh K: Intradialytic hypotension, blood pressure changes and mortality risk in incident hemodialysis patients. Nephrol Dial Transplant 33: 149-159 2018.

32. Emili S, Black NA, Paul RV, Rexing CJ and Ullian ME: A protocol-based treatment for intradialytic hypotension in hospitalized hemodialysis patients. Am J Kidney Dis 33: 1107-1114, 1999.

33. Daugirdas JT: Pathophysiology of dialysis hypotension: An update. Am J Kidney Dis 38 (4 Suppl 4): S11-S17, 2001.

34. Perazella MA: Pharmacologic options available to treat symptomatic intradialytic hypotension. Am J Kidney Dis 38 (4 Suppl 4): S26-S36, 2001.

35. Parker T III: Creating an open dialogue on improving dialysis care. Nephrol News Issues 27: 14,16, 2013.

36. Rayner HC, Zepel L, Fuller DS, Morgenstern H, Karaboyas A, Culleton BF, Mapes DL, Lopes AA, Gillespie BW, Hasegawa T, et al: Recovery time, quality of life, and mortality in hemodialysis patients: The dialysis outcomes and practice patterns study (DOPPS). Am J Kidney Dis 64: 86-94, 2014. 
37. Kuipers J, Verboom LM, Ipema KJR, Paans W, Krijnen WP, Gaillard CAJM, Westerhuis R and Franssen CFM: The prevalence of intradialytic hypotension in patients on conventional hemodialysis: A systematic review with meta-analysis. Am J Nephrol 49: 497-506, 2019.

38. Flythe JE, Curhan GC and Brunelli SM: Disentangling the ultrafiltration rate - mortality association: The respective roles of session length and weight gain. Clin J Am Soc Nephrol 8: $1151-1161,2013$

39. Lee MJ, Doh FM, Kim CH, Koo HM, Oh HJ, Park JT, Han SH, Yoo TH, Kim YL, Kim YS, et al: Interdialytic weight gain and cardiovascular outcome in incident hemodialysis patients. Am J Nephrol 39: 427-435, 2014

40. Palmer BF: Individualizing the dialysate in the hemodialysis patient. Semin Dial 14: 41-49, 2001.

41. Choi HY and Ha SK: Potassium balance in maintenance hemodialysis. Electrolyte Blood Press 11: 9-16, 2013.

42. Pun PH,Lehrich RW,Honeycutt EF,Herzog CA and Middleton JP. Modifiable risk factors associated with sudden cardiac arrest within hemodialysis clinics. Kidney Int 79: 218-227, 2011.

43. Kovesdy CP, Regidor DL, Mehrotra R, Jing J, McAllister CJ, Greenland S, Kopple JD and Kalantar-Zadeh K: Serum and dialysate potassium concentrations and survival in de-modialysis patients. Clin J Am Soc Nephrol 2: 999-1007, 2007.

44. Karaboyas A, Zee J, Brunelli SM, Usvyat LA, Weiner DE, Maddux FW, Nissenson AR, Jadoul M, Locatelli F, Winkelmayer WC, et al: Dialysate potassium, serum potassium, mortality, and arrhythmia events in hemodialysis: Results From the Dialysis Outcomes and Practice Patterns Study (DOPPS) Am J Kidney Dis 69: 266-277, 2017.

45. Stone M, Martyn L and Weaver C: Potassium intake, bioavailability, hypertension, and glucose control. Nutrients 8: 444 2016.

46. Putcha $\mathrm{N}$ and Allon $\mathrm{M}$ : Management of hyperkalemia in dialysis patients. Semin Dial 20: 431-439, 2007

47. National Kidney Foundation: Potassium and your CKD diet. https://www.kidney.org/atoz/content/potassium. Accessed May 15,2020 .

48. Basti C and Hayslett J: The cellular action of aldosterone in target epithelia. Kidney Int 42: 250, 1992

49. Young DB, Smith MJ Jr, Jackson TE and Scott RE: Multiplicative interaction between angiotensin II and K concentration in stimulation of aldosterone. Am J Physiol 247: E328-E345, 1984.

50. Mount DB and Zandi-Nejad K: Hyperkalemia. In: The Kidney. Brenner BM (ed.) PA: Saunders., Philadelphia, pp1017-1025, 2004.

51. U.S. Renal Data System: Annual Data Report: Reference Tables https://www.usrds.org/reference.aspx. Accessed May 15, 2020.

52. Lowrie EG and Lew NL: Death risk in hemodialysis patients: The predictive value of commonly measured variables and an evaluation of death rate differences between facilities. Am J Kidney Dis 15: 458-482, 1990.

53. Iseki $K$, Uehara $H$, Nishime $K$, Tokuyama $K$, Yoshihara $K$, Kinjo K, Shiohira Y and Fukiyama K: Impact of the initial levels of laboratory variables on survival in chronic dialysis patients. Am J Kidney Dis 28: 541-548, 1996.

54. Evans KJ and Greenberg A: Hyperkalemia: A review. J Intensive Care Med 20: 272-290, 2005

55. Martin RS, Panese S, Virginillo M, Gimenez M, Litardo M, Arrizurieta E and Hayslett JP: Increased secretion of potassium in the rectum of man with chronic renal failure. Am J Kidney Dis 8: 105-110, 1986.

56. Sandle GI, Tapster S and Goodship TH: Evidence for large intestinal control of potassium homeostasis in uremic patients undergoing long-term dialysis. Clin Sci (Lond) 73: 247-252, 1987.

57. Allon M, Takeshian A and Sanklin N: Effect of insulin-plus glucose infusion with or without epinephrine on fasting hyperkalemia. Kidney Int 43: 212-217, 1993.

58. Massry SG: Renal failure, parathyroid hormone and extrarenal disposal of potassium. Miner Electrolyte Metab 16: 77-81, 1990.

59. Goldfarb S, Cox M, Singer I and Goldberg M: Acute hyperkalemia induced by hyperglycemia: Hormonal mechanisms. Ann Intern Med 84: 426-432, 1976.

60. Moreno M, Murphy C and Goldsmith C: Increase in serum potassium resulting from the administration of hypertonic mannito and other solutions. J Lab Clin Med 73: 291-298, 1969.

61. Gennari FJ: Disorders of potassium homeostasis: Hypokalemia and hyperkalemia. Crit Care Clin 18: 273-288, 2002.

62. Ahmed J and Weisberg LS: Hyperkalemia in dialysis patients. Semin Dial 14: 348-356, 2001
63. Kim HJ: Pathogenesis and treatment of dyskalemia in maintenance hemodialysis and CAPD. Electrolyte Blood Press 4: 47-52, 2006.

64. Parham WA, Mehdirad AA, Biermann KM and Freman CS: Hyperkalemia revisited. Tex Heart Inst J 33: 40-47, 2006.

65. Szerlip HM, Weiss J and Singer I: Profound hyperkalemia without electrocardiographic manifestations. Am J Kidney Dis 7: 461-465, 1986.

66. Musso CG: Potassium metabolism in patients with chronic kidney disease. Part II: Patients on dialysis (stage 5). Int Urol Nephrol 36: 469-472, 2004

67. Pun PH and Middleton JP: Dialysate potassium, dialysate magnesium, and hemodialysis risk. J Am Soc Nephrol 28: 3441-3451, 2017.

68. Locatelli F, La Milia V, Violo L, Del Vecchio L and Di Filippo S: Optimizing haemodialysate composition. Clin Kidney J 8: 580-589, 2015.

69. Acker CG, Johnson JP, Palevsky PM and Greenberg A Hyperkalemia in hospitalized patients: Causes, adequacy of treatment, and results of an attempt to improve physician compliance with published therapy guidelines. Arch Intern Med 158: 917-924, 1998.

70. Hoskote SS, Joshi SR and Ghosh AK: Disorders of potassium homeostasis: Pathophysiology and management. J Assoc Physicians India 56: 685-693, 2008.

71. Hwang JC, Wang CT, Chen CA and Chen HC: Hypokalemia is associated with increased mortality rate in chronic hemodialysis patients. Blood Purif 32: 254-261, 2011.

72. Podrid PJ: Potassium and ventricular arrhythmias. Am J Cardiol 65: E33-E44; Discussion E52, 1990.

73. Zehnder C, Gutzwiller JP, Huber A, Schindler C and Schneditz D Low-potassium and glucose-free dialysis maintains urea but enhances potassium removal. Nephrol Dial Transplant 1: 78-84, 2001.

74. Weisberg LS and Rachoin JS: The safety of low-potassium dialysis. Semin Dial 23: 556-560, 2010.

75. Drueke TB and Lacour B: Disorders of calcium, phosphate, and magnesium metabolism. In: Comprehensive Clinical Nephrology. Freehally J, Floege J and Johnson RJ (eds.) Mosby-Elsevier, Philadelphia, pp123-140, 2007.

76. Toribara TY, Terepka AR and Dewey PA: The ultrafiltrable calcium of human serum. I. Ultrafiltration methods and normal values. J Clin Invest 36: 738-748, 1957.

77. Loken HF, Havel RJ, Gordan GS and Whittington SL: Ultracentrifugal analysis of protein bound and free calcium in human serum. J Biol Chem 235: 3654-3658, 1960.

78. Institute of Medicine (US) Committee to review dietary reference intakes for vitamin D and calcium; Ross AC, Taylor CL, Yaktine AL and Del Valle HB: Dietary reference intakes for calcium and vitamin D. Washington (DC): National Academies Press (US); 2011. Overview of calcium. Available from: https://www.ncbi.nlm.nih.gov/books/NBK56060/. Accessed May 20, 2020.

79. Papacocea T, Buraga I, Papacocea R, Badarau I, Buraga M, Ciornei $\mathrm{C}$ and Danil A: Antioxidant enzymes - potential targets in intracerebral haemorrhage. Farmacia 62: 1118, 2014.

80. Kidney disease: Improving Global Outcomes (KDIGO) CKD-MBD update work group: KDIGO 2017 Clinical practice guideline update for the diagnosis, evaluation, prevention, and treatment of chronic kidney disease-mineral and bone disorder (CKD-MBD). Kidney Int Suppl 7: 1-59, 2017.

81. Bailey RL, Dodd KW, Goldman JA, Gahche JJ, Dwyer JT, Moshfegh AJ, Sempos CT and Picciano MF: Estimation of total usual calcium and vitamin D intake in the United States. J Nut 140: 817-22, 2010

82. National Kidney Foundation: K/DOQI clinical practice guidelines for bone metabolism and disease in chronic kidney disease. Am J Kidney Dis 42 (4 Suppl 3): S1-S201, 2003.

83. Hoenderop JG, Muller D, Suzuki M, van Os CH and Bindels RJ: Epithelial calcium channel: Gate-keeper of active calcium reabsorption. Curr Opin Nephrol Hypertens 9: 335-40, 2000.

84. Bronner F and Stein WD: Calcium homeostasis - an old problem revisited. J Nutr 125 (Suppl 7): S1987-S1995, 1995.

85. van der Sande FM, ter Meulen KJA, Kotanko P and Kooman JP: Dialysate calcium levels: Do they matter? Blood Purif 47: 230-235, 2019

86. Saha H, Harmoinen A, Pietilä K, Mörsky P and Pasternack A: Measurement of serum ionized versus total levels of magnesium and calcium in hemodialysis patients. Clin Nephrol 46: 326-331, 1996. 
87. Block GA, Klassen PS, Lazarus JM, Ofsthun N, Lowrie EG and Chertow GM: Mineral metabolism, mortality, and morbidity in maintenance hemodialysis. J Am Soc Nephrol 15: 2208-2218, 2004.

88. Kalantar-Zadeh K, Kuwae N, Regidor DL, Kovesdy CP, Kilpatrick RD, Shinaberger CS, McAllister CJ, Budoff MJ, Salusky IB and Kopple JD: Survival predictability of time - varying indicators of bone disease in maintenance hemodialysis patients. Kidney Int 70: 771-780, 2006.

89. Savoiu Balint G, Iovanescu G, Stanca HT, Popoiu CM, Boia E, Popovici AR and Bolintineanu SL: The protective effect of HDL-cholesterol in patients with essential hypertension. Rev Chim Buchar 68: 949-952, 2017.

90. Timofte D, Ionescu D, Medrihan L, Mandita A, Rasina A and Damian L: Vascular calcification and bone disease in hemodialysis patients assessment, association and risk factors. Nephrology Dialysis Transplantation 22: 325-326, 2007.

91. Timofte D, Dragos D, Balcangiu-Stroescu A-E, Tanasescu M-D, Balan DG, Raducu L, Tulin A, Stiru O and Ionescu D: Abdominal aortic calcification in predialysis patients: Contribution of traditional and uremia-related risk factors. Exp Ther Med 20: 97-102, 2020.

92. Stevens LA, Li S, Wang C, Huang C, Becker BN, Bomback AS, Brown WW, Burrows NR, Jurkovitz CT, McFarlane SI, et al Prevalence of CKD and comorbid illness in elderly patients in the United States: Results from the Kidney Early Evaluation Program (KEEP). Am J Kidney Dis 55 (3 Suppl 2): S23-S33, 2010.
93. Miller JE, Kovesdy CP, Norris KC, Mehrotra R, Nissenson AR, Kopple JD and Kalantar-Zadeh K: Association of cumulatively low or high serum calcium levels with mortality in long-term hemodialysis patients. Am J Nephrol 32: 403-413, 2010.

94. Duval M, Bach K, Masson D, Guimard C, Le Conte P and Trewick D: Is severe hypocalcemia immediately life-threatening? Endocr Connect 7: 1067-1074, 2018.

95. Jimenez ZN, Silva BC, Reis LD, Castro MC, Ramos CD Costa-Hong V, Bortolotto LA, Consolim-Colombo F, Dominguez WV, Oliveira IB, et al: High dialysate calcium concentration may cause more sympathetic stimulus during hemodialysis. Kidney Blood Press Res 41: 978-985, 2016.

96. McGill RL and Weiner DE: Dialysate composition for hemodialysis: Changes and changing risk. Semin Dial 30: 112-120, 2017.

97. Pun PH, Horton JR and Middleton JP: Dialysate calcium concentration and the risk of sudden cardiac arrest in hemodialysis patients. Clin J Am Soc Nephrol 8: 797-803, 2013.

98. Genovesi S, Rossi E, Nava M, Riva H, De Franceschi S, Fabbrini P, Viganò MR, Pieruzzi F, Stella A, Valsecchi MG and Stramba-Badiale M: A case series of chronic hemodialysis patients: Mortality, sudden death, and QT interval. Europace 15: 1025-1033, 2013.

This work is licensed under a Creative Commons Attribution-NonCommercial-NoDerivatives 4.0 International (CC BY-NC-ND 4.0) License. 